\title{
Jacques Rancière e a revolução sensível: uma (outra) leitura política de Madame Bovary $^{1}$
}

\section{Jacques Rancière and the sensible revo- lution: a (another) political reading of Madame Bovary}

\begin{abstract}
Daniela Cunha Blanco
Mestranda em Filosofia pela Universidade de São Paulo e membro do Grupo de Estudos em Estética Contemporânea da USP.
\end{abstract}

Resumo: O intuito desse texto é pensar como a análise empreendida por Jacques Rancière em torno do livro Madame Bovary, de Gustave Flaubert, daria a ver um entrelaçamento entre estética e política latente tanto na história de Emma Bovary quanto nas críticas a ela dedicadas. Passando especialmente pelas interpretações de Charles Baudelaire e de Jean-Paul Sartre pretende-se apresentar a ideia de que o modo como ambos pensam os gestos e atitudes da personagem é, antes de tudo, político. Se Sartre aproxima o tema de Emma a uma discussão política pela via da práxis e do imaginário, Rancière apresenta uma leitura do romance que não apenas coloca-o em outra chave de visibilidade como também, a partir desse novo olhar, reinterpreta 0 próprio campo estético em suas relações com a política. Trata-se de pensar o poder de afetar e transformar vidas que a materialidade do sensível do texto daria a ver; de pensar aquilo que compreende como

$1 \quad$ pesquisa financiada pelo CNPQ 
uma revolução sensível. Desse modo, a aproximação da personagem Emma ao pensamento político da emancipação se dará pela via da partilha do sensível que tanto a personagem quanto os proletários das revoluções francesas do século XIX teriam empreendido ao exceder a ligação entre um modo de aparecer e um modo de ser.

Palavras-chave: Revolução sensível; Madame Bovary; Estética e política, Jacques Rancière

\begin{abstract}
The purpose of this text is to think how Jacques Rancière's analysis of Gustave Flaubert's book, Madame Bovary, could show an interweaving between aesthetics and politics in Emma Bovary's history as much as in the critiques dedicated to it. Especially in to the interpretations of Charles Baudelaire and Jean-Paul Sartre, we intended to present the idea that the way they both think the gestures and attitudes of the character is, first of all, political. If Sartre relates the subject of Emma to a political discussion through praxis and imaginary, Rancière presents a reading of the novel that not only places it in another key of visibility but also, from this new point of view, reinterprets the aesthetic field itself in their relations with politics. It is about thinking the power to affect and transform lives that the materiality of the sensible of the text would show, to think what Rancière understands as a sensible revolution. In this way, Emma's approach to the political thought of emancipation will be made through the concept of divison of the sensible that both the character and the proletarians of the French revolutions of the nineteenth century would have undertaken by overcoming the connection between a way of appearing and a way of being.
\end{abstract}

Keywords: Sensible revolution; Madame Bovary; Aesthetics and politics, Jacques Rancière

\title{
Introdução
}

O romance escrito por Gustave Flaubert em 1857, Madame Bovary, já foi tema e objeto de diversas teorizações e debates ao longo dos anos. A personagem que movimenta a narrativa, as descrições excessivas de eventos de menor importância, dentre 
outros elementos, parecem suscitar interesses diversos que levaram pensadores e escritores a discutir moral, arte e política a partir de desdobramentos do livro em questão. O intuito desse texto é pensar como a análise realizada por Jacques Rancière em torno do livro em questão daria a ver um entrelaçamento entre estética e política latente tanto na história de Emma Bovary quanto nas críticas a ela dedicadas. Passando especialmente pelas interpretações de Charles Baudelaire e de Jean-Paul Sartre pretende-se apresentar a ideia de que o modo como ambos pensam os gestos e atitudes da personagem, dirigindo-lhe críticas, elogios ou condenações, é, antes de tudo, político.

Apresentando sua interpretação de Emma Bovary, Baudelaire (2011), ao identificar uma diferença entre uma natureza feminina e outra masculina para analisar os desejos e atitudes adúlteras de Emma, teria feito a discussão cair em um âmbito moral. Sartre (2013, 2014, 2015) por sua vez, aplicou-se a um imenso trabalho na escrita dos volumes que compõe $O$ idiota $d a$ família, no qual dedica-se a uma análise de Gustave Flaubert e de suas obras. Quando se refere a Emma, o autor demonstra não estar preocupado exatamente com o adultério cometido pela personagem, mas sim com aquilo que nela, assim como em seu autor, lhe poderia fazer refletir sobre as mesmas questões que teriam sido grandes temas de seu pensamento: a práxis política e o imaginário. Acreditava que ao analisar a vida de um homem estaria, ao mesmo tempo, refletindo sobre o tempo e o contexto no qual aquele vivia. Desse modo, a análise da trajetória e das características de Emma estariam, de certa forma, subjugadas a um intuito maior da obra, a saber, compreender as relações entre a burguesia e a classe operária no período pós-revoluçõos do século XIX na França.

Muito tempo depois, em um momento no qual já se pudesse talvez afirmar que o excesso de interpretações de Madame Bovary teria já tornado inócua qualquer nova abordagem, Rancière apresenta uma leitura do romance que não apenas coloca-o em outra chave de visibilidade como também, a partir desse novo olhar, reinterpreta o próprio campo estético e as relações entre arte e política nele postos. Para o autor, não se 
trata de pensar a personagem a partir da verossimilhança com seu tempo, tampouco a partir de um caráter psicológico dela ou do autor do romance. Trata-se, antes, de pensar o poder de afetar e transformar vidas que a materialidade do sensível do texto daria a ver, de pensar aquilo que compreende como uma revolução estética. Tal ideia passa por uma reformulação da relação entre estética e política, que deve ser compreendida como uma relação intrínseca na qual não se pode pensar uma sem que a outra esteja necessariamente implicada. O autor dá a ver, em sua leitura de Madame Bovary, que o desejo da personagem por viver os sentimentos destinados à elite - dos quais toma conhecimento através da literatura - demonstrariam o poder do sensível de transmutar as vidas daqueles que encontram-se com ele.

Essa experiência sensível apareceria também nas análises dedicadas por Rancière às revoluções operárias do início do século XIX na França. O autor fala, em seu livro A noite dos proletários, sobre os operários que empregavam seu tempo livre a escrever poesias e manifestos. Apresentaremos uma aproximação entre os operários-poetas-revolucionários - tal qual pensados pelo autor - e a personagem Emma Bovary, com o intuito de traçar entre ambos uma linha comum, a saber, aquela que diz respeito às capacidades do sensível de reconfigurar os modos de visibilidade que delimitam nossos modos de vida. Desse modo, a questão das relações entre arte e revolução operária - que também interessava a Sartre - será recolocada de um modo totalmente diverso a partir do pensamento de Rancière. Com isso, as interpretações do livro Madame Bovary e suas possíveis relações com a política serão apresentadas de modo a pensarmos um novo modo de visibilidade da arte e de sua capacidade crítica.

\section{Imoralidade e traição da realidade: da recepção de Madame Bovary}

O romance Madame Bovary recebeu críticas acaloradas - tanto no período de sua publicação quanto posteriormente - 
que teriam imputado a Flaubert o epíteto de imoral. Laurence M. Porter e Eugene F. Gray (2002), em Gustave Flaubert's Madame Bovary: a reference guide, afirmam que Flaubert teria sido atacado por Barbey D'Aurevilly "por ter sucedido em ter criado um narrador invisível, desapaixonado, que deixa os eventos e seus desdobramentos falarem por si próprios" (Porter e Gray, 2002, p. 118). Os mesmo autores do compêndio sobre Madame Bovary, apontam, ainda, uma crítica semelhante, dessa vez, feita por Charles Batteux, que apontava a necessidade de que a literatura fosse pensada a partir da intervenção necessária do autor na história com o intuito de mostrar as virtudes e condenar os vícios, mostrando, assim, ao leitor, o que sentir (1969, p. 20-22 apud Porter e Gray, 2002, p. 126-127). Opondo-se a isso, Baudelaire (2011) responde às denúncias da suposta imoralidade da obra: "Absurdo! Eterna e incorrigível confusão das funções e dos gêneros! - Uma verdadeira obra de arte não precisa de requisitório. A lógica da obra basta para todas as postulações da moral, e é o leitor quem deve tirar as conclusões da conclusão" (Baudelaire, 2011, p. 13).

Apesar de elogiar o autor e a obra, Baudelaire não escapa, porém, de uma crítica moral, chegando a afirmar que Emma Bovary teria sido ornada por Flaubert, "com todas as qualidade viris" que a tornariam inverossímil (Baudelaire, 2011, p. 14.). A reunião, em uma personagem mulher, das características do homem ideal com as do animal puro, ainda segundo Baudelaire, teria elevado as mulheres a uma alta potência, fazendo-as "participar desse duplo caráter de cálculo e de sonho que constitui o ser perfeito" (Baudelaire, 2011, p. 16). Para o autor, Flaubert teria criado uma personagem incrível ao reunir um lado mais imaginativo que seria, segundo ele, próprio da natureza feminina, a um outro mais racional, próprio à natureza masculina. É interessante notar como o motivo dos elogios de Baudelaire tornariam-se, mais tarde, estímulo das críticas realizadas por Sartre $(2013,2014,2015)$ à mesma personagem e suas desventuras ao longo do livro. Se para Baudelaire a mistura entre o sonho e a razão culminariam na criação de um ser ideal (consideremos a afirmação de que apenas um homem poderia servir como modelo ideal como fruto das limitações político-sociais e 
intelectuais de uma época), para Sartre a tentativa de realizar no mundo real, aquele dominado pela razão, os sonhos do imaginário, seria o motivo da ruína e do suicídio de Emma Bovary.

Hazel E. Barnes, no livro Sartre e Flaubert, resume a visão de Sartre sobre Emma da seguinte forma:

O que enobrece Emma é que ela estima um sonho por algo além daquilo que esse mundo da mortalidade humana pode satisfazer. Ela toma parte da grandeza da insatisfação. A causa de seu sofrimento, o que inclusive a torna ridícula, é o fato de ela falhar em entender que o que ela deseja é irreal e não pode ser satisfeito no mundo. $O$ que ela trai não é o real mas o imaginário. Ter lutado para se contentar com a devoção de Charles e a adoração idealística de Justin teria sido tão travesso quanto a tentativa dela de encontrar completude em suas relações com Léon e Rodolphe. É errado pensar que um marido diferente ou um ambiente mais estimulante teria prevenido a tragédia. Nenhum homem em nenhuma cidade poderia ter satisfeito o desejo dela por aquilo que não existe a não ser no imaginário. (Barnes, 1981, p. 344)

Para Sartre, Emma Bovary padecia do mesmo mal que Dom quixote, personagem do livro homônimo de Cervantes. Ambos teriam traído o imaginário. Não se trata apenas de escolher o imaginário no lugar da realidade, mas sim de acreditar poder transpor os sonhos ao mundo real. Sartre (2013) fala de como Flaubert teria se reconhecido no personagem Dom Quixote, ambos devotados a uma glória para a qual não possuiam as qualidade necessárias - Dom quixote por viver fora de seu tempo e Flaubert, por ser o idiota da família, o segundo filho. A genialidade de Flaubert, assim, segundo Sartre teria sido a de reconhecer-se, tal qual Dom Quixote, como um trabalhador do impossível. Assim, Flaubert

interpretará o sub-homem que se considera um homem, o covarde que se considera um durão, o magricela que se considera um matamouros, extraindo seu talento da imperícia e aplicando sua grandeza em declarar que, para além do ridículo que se prende justamente aos sonhadores, é belo considerar-se, contra todas as dificuldades, aquele que sabemos que não podemos ser. (Sartre, 2013, p. 840) 
Mas Sartre (2013) interpreta com mal agouro o trabalhador do impossível, afirmando que sua genialidade e glória serão também seu pesadelo. Afinal, Flaubert, assim como Dom Quixote, acredita fazer rir quando é apenas objeto da risada. Para Sartre, afinal, não se pode desejar ser em ato aquilo que se sonha e imagina.

Para Sartre (2014), só haviam duas coisas que poderiam salvar Emma, tal qual o autor de seu livro: arte ou morte. Apenas essas duas coisas poderiam fazê-los escapar da dura realidade. Flaubert o teria feito através da escrita, já à Emma, que não sabia fazer as coisas da arte, teria restado apenas o suicídio. Desse modo, compreende-se como Sartre afasta-se das críticas anteriores à personagem que teriam se pautado no adultério de Emma, seja para condená-la como imoral, seja para caracterizá-la como um personagem que só poderia ser pensado como representante de um homem em sua virilidade. O erro da personagem, diz Sartre (...), não seria ter cometido adultério, mas sim ter acreditado que algo no plano real - Charles, Rodolphe ou Léon - poderiam ser a completude de seus desejos.

A partir dessa ideia Sartre diz ainda que Emma teria perdido sua autenticidade em certo ponto da narrativa. Após ter se entregado a Rodolphe na floresta, retorna para casa, olha-se no espelho e relembra o cenário da paixão consumada: a floresta e as árvores ao redor, as folhagens, os juncos e diz para a imagem do espelho, excitada e alegre, que agora tem um amante. A impressão de Sartre é a de que "a inautenticidade começa para ela com o retorno da linguagem" (Sartre, 2014, p. 1289). A partir desse momento, como explica Barnes, "ela vê a si mesma, não como estava na floresta, mas como em um livro, uma das incontáveis heroínas cujas paixões ela queria experienciar como delas mesma. Ela tornou-se inautêntica" (Barnes, 1981, p. 353). Seu crime, portanto, teria sido o de desejar ser outra, de realizar, na vida real, os sonhos das personagens da literatura.

As críticas direcionadas a Emma e a seu autor por Sartre ligam-se a uma questão mais ampla do contexto político vivido por Flaubert e sua geração, que lidavam com aquilo que havia lhes restado após a Revolução Francesa. Fredric Jameson, em 
um artigo publicado em 1981, discorre sobre o Idiota da família nos seguintes termos:

Sartre articula dois níveis de dilema: a crise da séria classe média artística em um sistema de mercado, confrontada com uma audiência em desaparição; e a crise ideológica da burguesia francesa, que durante a Revolução Francesa havia inventado a noção de uma natureza humana universal como uma arma contra a aristocracia, para apenas encontrar-se confrontada nos dias da revolução de 1848 com uma nova classe desfavorecida proletária em relação a qual relutava em reconhecer como parte daquela humanidade universal. A burguesia irá 'resolver' esse novo problema tornando-se Vitoriana, reprimindo a 'natureza' animal e física que parecia compartilhar com os proletários e transformando seu humanismo anterior em um positivismo misantropo. (Jameson, 1981, tradução nossa)

Assim, a geração anterior havia concebido uma ideia de natureza humana universal sem contar com ter que lidar posteriormente com uma classe proletária com a qual não se identificava e que gostaria de ver desidentificada da humanidade burguesa. Havia, agora, em Flaubert e em seu tempo, uma necessidade de separar os desejos incontroláveis do proletariado daqueles mais dignos da burguesia. Como afirma Sartre, em um exemplo de uma revolta estudantil ocorrida na escola de Flaubert no ano anterior a seu ingresso nela, ainda criança, os alunos

tiram lições da experiência paterna e a aproveitam para evitar repeti-la. Têm o poder, é verdade, mas não serão tolos a ponto de compartilha-lo com as classes desfavorecidas; por esse motivo, o melhor é esconder o que têm. De que adianta expulsar a aristocracia se for para substituí-la por uma plutocracia ostensiva que cedo ou tarde engendrará a aberração democrática em meio a perturbações? (Sartre, 2014, p. 1346)

Quando Emma realiza seus desejos mais baixos na floresta, fundindo-se com ela, as folhas, o vento, ela se torna igual à classe proletária, como se realizasse em ato a ideia de uma humanidade universal. Mas quando retorna à casa e relembra a cena, tornando-a parte de uma história de amor burguesa tal qual aquelas lidas nos romances, Emma mostra-se como uma vitoriana, reprimindo os desejos sob a cobertura de uma história aburguesada. 
Desse modo, compreende-se como a história da esposa adultera de um médico de província liga-se com a questão da política tanto em Flaubert quanto em Sartre. Trata-se, afinal, de pensar como a relação entre imaginário e práxis - para usar os termos sartrianos - aparecem entrelaçados nos gestos, desejos e sonhos da personagem.

Isso remete diretamente ao contexto no qual Sartre dedica-se a escrita dos volumes de $O$ idiota da família. Nos dez últimos anos de sua vida, em meio a uma militância constante, com o surgimento das lutas de maio de 1968, mesmo sendo incitado pelo companheiros de luta a escrever um tratado comunista, Sartre dedica-se a um projeto imenso em torno de um autor que detestava especialmente por sua posição política conservadora. Para compreender como seria possível entrelaçar essas duas camadas desse momento da vida e do pensamento de Sartre, Jameson afirma:

Se, entretanto, vê-se o tema do imaginário em uma tensão dialética inseparável daquele outro tema da vida toda do trabalho de Sartre, que é a práxis, então, a devoção teimosa de Sartre a seu projeto de Flaubert torna-se mais compreensível; o estudo do 'imaginário' pode ser comprendido como um autodiagnóstico da 'neurose objetiva' da burguesia, enquanto a práxis - ação deliberada no mundo real - permanece como a projeção de um modo de atividade radicalmente diferente, identificado com o proletariado. (Jameson, 1981, tradução nossa)

Desse modo, compreende-se que a leitura que Sartre faz da personagem Emma Bovary e de Flaubert está diretamente associada a uma ideia de política pensada a partir da práxis. Sartre opõe a passividade da obediência ao agir político. A leitura das camadas do romance aparece, assim, subordinada a tal hieraquia preocupada em pensar as possibilidades da ação política expressas no texto, que dariam a ver, por sua vez, a relação de Flaubert com a política e as questões sociais de seu tempo. Afinal, afirma Sartre já no prefácio do primeiro grande volume de $O$ idiota da família, "um homem nunca é um indivíduo; seria melhor chamá-lo de universal singular: totalizado e por isso mesmo, universalizado por sua época, ele a retotaliza ao reproduzir-se nela como singularidade" (Sartre, 2013, p. 
7). Ao estudar a vida de um homem singular, Sartre pretendia compreender nele todo o sentido e conflitos de uma época.

Apesar dos diferentes tratamentos dados ao tema, há algo que aparece como ponto comum nas interpretações da personagem Emma Bovary apresentadas brevemente. Para Barbey D'Aurevilly (1986 apud 2002) e Batteux (1969 apud 2002), o problema do livro estaria no fato de o autor ausentar-se demais dos caminhos da narrativa, deixando à personagem uma certa liberdade que não teria proporcionado nenhum exemplo de virtude moral, mas, antes, um exemplo de imoralidade. Pode-se dizer, assim, que haveria nesses autores uma certa ideia de que os sonhos e os desejos deveriam ser refreados por uma razão ordenadora da narrativa que daria a ver, por sua vez, uma certa ordenação moral da vida. Já Baudelaire (2011), apesar de discordar da necessidade de que a literatura tenha uma intervenção moral do autor, aponta um estranhamento na virilidade da personagem mulher a partir também da ideia de uma relação entre um desejo desordenado do animal puro e uma razão ordenadora do homem ideal, afirmando que essa relação, tal qual apareceria em Emma, teria elevado o ideal das mulheres. Esse mesmo terreno das relações entre a razão e o sonho foi retomado por Sartre sob outros termos, colocando a questão do imaginário dos desejos e sua relação com a razão da práxis política a partir da ideia de que o imaginário não pode ser traído pela ideia de sua realização no mundo real.

Rancière, por sua vez, pensa os desejos e paixões de Emma Bovary a partir de uma outra visibilidade que pode ser compreendida como um desejo de ser e sentir-se como aquilo que não é permitido a alguém por motivos de origem, classe ou gênero. Para o autor, o desejo de Emma de viver as histórias de amor que não lhe eram destinadas daria a ver uma desordenação da razão que seria essencialmente política. Em um sentido diverso daquilo que pensava Sartre sobre essa confusão entre sonho e razão, Rancière a vê como exatamente aquilo que conseguiria liberar os indivíduos de uma ordem policial compreendida como aquela que lhes destina a ocupar o espaço e o tempo de acordo com sua identificação. Desse modo, se a Emma não cabia sentir as paixões dos romances que lia, ao realizar esses 
desejos do âmbito do imaginário - para colocar Rancière em diálogo com Sartre - ela estaria operando uma razão política que a desobrigaria de qualquer destinação ou origem. Ela operaria o que Rancière denomina de uma revolução estética, compreendida como uma reconfiguração dos modos de visibilidade do tecido político ${ }^{2}$. Emma, a partir da leitura de Rancière, em sua ousadia de realizar em sua vida os desejos emprestados dos romances destinados à elite, pode ser aproximada da discussão política em torno da revolução operária por um caminho diverso daquele abordado por Sartre, mas para isso, a própria interpretação da ideia de revolução operária deve ser repensada.

Ambas as revoluções, as de Emma e as dos proletários franceses do início do século XIX, passam pela ideia de que o desejo de ser outro opera já uma reconfiguração do espaço e do tempo. O que significa pensar que não existiria traição do imaginário, tal qual afirmava Sartre, tampouco que o desejo seria algo do âmbito irracional em oposição à razão, como pensava Baudelaire; antes, implica pensarmos que o desejo de ser outro apresenta um modo da razão capaz de mover as peças no jogo social, transformando os modos de visibilidade e liberando os desejos dos indivíduos de suas identificações sociais. Os sonhos não estão associados àquilo que se pode sonhar, são, antes, apenas aquilo que se sonha e que ao fazê-lo, reconfiguramos nossos modos de vida.

\section{A poesia dos proletários e a paixão da filha de camponeses}

Rancière apresenta uma leitura particular de Emma Bovary que tem como intuito libertar sua paixão do local de disputa do pensamento no qual teria sido incluída anteriormente. $2 \quad$ Para compreender o que estaria em jogo na ideia de revolução estética faz-se necessário pensar a estética e a política tais quais elas são pensada pelo autor. Tudo aquilo que é político é também essencialmente estético, pois a política trata do tecido sensível no qual as divisões e partilhas delimitam e configuram os espaços ocupados pelos indivíduos. A política nada mais é do que as formas de visibilidade sob as quais a ordem social aparece. Mas existem duas formas sob as quais essa partilha opera: a razão policial, que se empenha por delimitar os espaços e tempos associando um modo de visibilidade a um modo de ser e; a razão política, aquela que desidentifica o conceito da realidade, o ser do aparecer, operando uma reconfiguração do sensível. 
Pode-se pensar, a partir de sua leitura, como Sartre, Baudelaire e outros teóricos, ao debruçarem-se sobre a personagem condenando-a por seus desvios ou, ainda, querendo direcionar uma realização mais adequada de seus desejos, teriam mostrado a mesma faceta que se apresentaria nas discussões em torno das revoluções operárias do início do século XIX ocorridas na França. Se Emma teria sido esmiuçada por suas paixões e desejos, Rancière apresenta o modo como os operários em questão teriam também sido objeto de pensamento por empregarem seu tempo livre para criar textos, manifestos e poesias. Tal qual a paixão de Emma, a poesia escrita por operários teria sido objeto de escrutínio e de inúmeras intervensões feitas por aqueles que consideravam-se acima em algum grau intelectual ou social, e que, por esse motivo, alegavam-se o direito de reordenar a narrativa, de colocar os desejos de Emma ou os dos proletários em seu lugar.

No livro A noite dos proletários, publicado em 1981 como resultado de sua tese de doutorado, Rancière remete-se ao próprio nome do livro não como metáfora, mas de maneira literal, apontando para a ideia de uma desordenação do tempo e espaço pelos operários-poetas-revolucionários que ocupavam suas noites com atividades intelectuais, quando se esperava deles, que dormissem e recuperassem forças para o trabalho do corpo que o dia seguinte lhes destinava (Rancière, 2012a, p. 7). A partir de uma longa pesquisa dos arquivos de textos, publicações e cartas dos operários, o autor dá a ver como a disputa em torno do modo como estes deviam empregar seu tempo livre mostrava uma faceta estética da política que tratava de identificar um conjunto de indivíduos - sob o epíteto de classe - com o intuito de dominá-los. A dominação de que trata o autor, no entanto, não diz respeito à ideia de que os trabalhadores seriam alienados e precisariam ser conscientizados de sua condição; antes, trata-se de pensar que a dominação é uma forma de configuração da visibilidade de certos indivíduos na sociedade de tal modo que eles apareçam identificados, por seu modo de aparecer, àquilo que lhes imputam ser. Nesse jogo dos modos de visibilidade toda uma miríade de preocupações do âmbito estético são movidas com o intuito de tornar harmônica a correspondência entre o aparecer e o ser dos operários. 
O embelezamento da casa comum, do arrelvamento da esplanada, do cultivo das flores, da decoração do refeitório, das toalhas enceradas a colocar sobre suas mesas mal acabadas e da substituição do serviço de ferro forjado 'que parece preto, mesmo quando está limpo', por um serviço de louça: questões desprovidas de qualquer frivolidade, pois este esforço de elegância destinado a 'fazer a propaganda pelos olhos' tem de contribuir, juntamente com a reforma dos hábitos proletários, para atrair as capacidade e os capitais 'que simpatizam com a causa do Povo'. (Rancière, 2012, p. 350)

No contexto das revoluções operárias retratadas no livro em questão, havia toda uma preocupação com a moralização da classe proletária com a intenção de formar uma imagem coesa de conjunto que deveria estar refletida em cada indivíduo. A partir das vestimentas, da organização da casa, dos gestos e das palavras, devia-se perceber a aparência de um operário - nunca a de um burguês - assim como devia-se perceber sua aproximação com os ideiais comunistas. Compreende-se com isso como a questão política é essencialmente também estética. Afinal, trata-se de pensar o que Rancière denomina de partilha do sensível, compreendida como

um recorte dos tempos e dos espaços, do visível e do invisível, da palavra e do ruído que define ao mesmo tempo o lugar e o que está em jogo na política como forma de experiência. A política ocupa-se do que se vê e do que se pode dizer sobre o que é visto, de quem tem competência para ver e qualidade para dizer, das propriedades do espaço e dos possíveis do tempo. (Rancière, 2009a, p. 16-17)

Assim também em Flaubert percebe-se a possibilidade de identificar cada membro da sociedade ligado a uma determinada classe social a partir de suas vestimentas e gestos. É o que demonstra a descrição da festa de casamento de Emma e Charles Bovary: "as senhoras, de chapéu, tinham vestidos à moda da cidade, correntes de ouro nos relógios, capas de pontas cruzadas na cintura" (Flaubert, 2011, p. 104); outros, ainda "que (com certeza, deviam comer na ponta da mesa) usavam blusas de cerimônia, quer dizer, cuja gola era rebatida sobre os ombros, as costas plissadas em pequenas pregas e a cintura amarrada bem baixa com um cinto costurado", diferentes daqueles que vestiam paletós de panos grossos (Flaubert, 2011, 
105). O pai de Charles, Sr. Bovary, "tinha vindo simplesmente com uma sobrecasaca em estilo militar com uma fileira de botões", demonstrando, pela simples escolha da roupa, todo o desprezo que tinha por aquela gente da província (Flaubert, 2011, p. 106).

Do mesmo modo como pode-se identificar a origem social de cada personagem simplesmente pela descrição de suas roupas, as críticas de Baudelaire à Emma, de certa forma, reproduzem essa ideia de que os desejos da personagem deveriam condizer com sua modo de aparecer no mundo. E apesar de achar interessante sua personalidade viril, ao denominá-la assim, estaria relacionando uma determinada visibilidade que lhe faltaria a um modo de ser que consideraria natural ao gênero feminino. Estabeleceria, com isso, aquilo que Rancière afirma como uma certa ideia de natureza a partir da "identidade entre o conceito e a realidade" (Rancière, 2012, p. 314), na qual "o parecer não se deixa separar do ser" (Rancière, 2012, p. 251). Sartre, por sua vez, não condenava o adultério de Emma, mas sim seu desejo de querer experienciar na vida as palavras "felicidade, paixão e embriaguez, que lhe tinham parecido tão belas nos livros" (Flaubert, 2011, p. 114). O sexo com outros homens fora do casamento, portanto, não apareceria como um problema, antes, faria parte de uma certa natureza menos lapidada das classes menos favorecidas. Mas acreditar que essa natureza poderia ligar-se àquela ordem superior dos homens - a imaginação - transformando-a em realidade, teria sido o crime de Emma.

Crime semelhante é imputado aos proletários sobre os quais escreve Rancière. Assim os condenavam a imprenssa burguesa que denunciava "a presunção que impele os operários a trocar a ferramenta pela pena, e assimiliar a dedicação e os projetos dos operários ao desejo egoísta de se elevarem acima da condição popular" (Rancière, 2012, p. 258). Em outros momentos, porém, não eram condenados pelo simples fato de escreverem - afinal deviam militar pela causa e a produção de textos era parte importante da empreitada -, mas criticava-lhes o modo como escreviam, tal qual os burgueses, como se qui- 
sessem imitar-lhes o estilo quando deveriam criar um modo próprio que deixasse clara sua origem. Absurdo seria a um operário imaginar-se apto aos pensamento nobres de um burguês. Traição com a causa. Afinal, vê-se "na materialidade dos trabalhos que [os operários] executam e na rudeza dos ócios, no vazio do pensamento e no fenecimento da carne as marcas da pertença a uma raça inferior" (Rancière, 2012, p. 239).

Se emprestamos o olhar que Rancière deseja direcionar a essas figuras da história e da literatura - Emma Bovary e os operários-poetas-revolucionários da França do século XIX - pode-se perceber o deslocamento em relação ao modo de visibilidade que lhes foi conferido por Sartre ou Baudelaire. Se para estes o sensível é a textura do real a partir da qual pode-se ver simplesmente uma narrativa de origem e de destinação de um indivíduo que lhe determinariam os desejos e a possibilidade de realizá-los no real, para Rancière a materialidade sensível dá a ver ainda algo mais: o poder de desidentificação, de dissociar um modo de ser de um modo de aparecer, de reconfigurar a visibilidade daquilo que se pensava estar já cristalizado em uma imagem imutável. Rancière afirma que

não há reivindicação operária que não desenhe, contra as cenas de gênero que lhe são imputadas pelo inimigo, o verdadeiro retrato do trabalhador. Mas também não há verdadeiro retrato do trabalhador que não se esquive imediatamente, que não penetre, por via do próprio poder conferido à imagem identificadora, na espiral que vai da insignificância dos hieróglifos da criança até aos sonhos adultos de uma outra vida". (Rancière, 2012, p. 21-21)

Assim, quando se espera mostrar na aspereza das mãos a impossibilidade de uma ocupação intelectual, estando elas destinadas ao peso e a dureza das ferramentas, pode-se aí vê-la em um gesto delicado que contrasta com a rudeza do trabalho. Do mesmo modo, quando se espera de Emma que cada gesto seu expresse uma feminilidade universal, descobre-se a impossibilidade dessa universalidade.

O que esse sensível dá a ver, na leitura de Rancière, tanto em Emma quanto nos operários, é que antes mesmo de haver uma luta política explícita, há um desejo de ser e sentir- 
se como outro. O que não significa que a luta por direitos seja inútil ou colocada em segundo plano pelo autor, mas sim que para que o próprio desejo de alcançar um maior espaço social ocorra, há antes um desejo estético. Não se trata de conhecer ou conscientizar-se dos processos de dominação externos, mas sim de reconhecer em si mesmo outra destinação, de dissociar aquilo que deseja ser da imagem de si que lhe é imputada.

É do segredo dos outros que o proletário tem necessidade para defninir o sentido da sua própria existência e da sua própria luta; não do 'segredo da mercadoria': o que há aí que não seja claro como o dia? Ora, não é do dia que se trata, mas da noite; não da propriedade dos outros, mas da sua 'mágoa', essa dor inventada que contém todas as dores reais. Para que o proletário se erga contra 'o que se prepara para o devorar', não é conhecimento da exploração que lhe falta, é um conhecimento de si que the revele um ser destinado a algo distinto da exploração: revelação de si que passa pela apropriação do segredo dos outros, esses intelectuais e esses burgueses com os quais eles dirão mais tarde - e nós repetiremos depois - que não querem ter nada a ver, e menos ainda com a distinção entre bons e maus". (Rancière, 2012, p. 29)

O mesmo ocorre com a personagem Emma Bovary que descobre um desejo de sentir e viver as palavras que conheceu nos livros. A mudança na sensibilidade é o que possibilita ao operário, a Emma ou a qualquer indivíduo, sentir-se fazendo parte do jogo político e nele desejar intervir. Não é por acaso que os termos que vão surgindo aqui e ali ao longo do denso livro A noite dos proletários, parecem operar desvios em relação às abordagens comuns do tema. Formas de existência, modos de vida, indivíduos sensíveis, questão de aparência, comunidade de olhar, matéria sensível (Rancière, 2012a). Elementos que parecem suspender - ao invés de explicar -, as relações de opressão e dominação, as formações de movimentos de resistência, os processos de identificação e desidentificação. Afinal,

para que o protesto das oficinas tenha uma voz, para que a emancipação operária ofereça um rosto visível, para que os proletários existam como sujeitos de um discurso coletivo que dê sentido à multiplicidade das suas concentrações e dos seus combates, é preciso que estas pessoas se tenham já feito outras, na dupla e irremediável exclusão de viver como os operários e de falar como os burgueses". (Rancière, 2012a, p. 9) 
Nessa vida entre viver como operários e falar como burgueses, os modos de visibilidade dos operários, sejam em formas coletivas ou individuais, são reconfigurados. Tudo se passa, para Rancière, como se fosse possível fazer surgir, da materialidade do sensível, das coisas inanimadas, imagens desse ser outro dos operários. Essas imagens seriam como a possibilidade de sentir e experiênciar a textura do real. Como se o real fosse sempre permeado por um modo de sentir e perceber que determinaria aquilo mesmo que somos capazes de intuir daquilo que vemos e vivemos. Do mesmo modo, Emma vive como filha de camponeses, mas já sente-se como aquele outro que deseja ser. No livro O fio perdido: ensaios sobre a ficção moderna, publicado em 2013, Rancière escreve sobre Emma como se a transposse para a mesma cena do livro de 1981 (A noite dos proletários), como se sobrepusesse Emma e a questão operária em um mesmo espaço-tempo.

Mas a história de Emma, que desejava verificar em sua vida o sentido de algumas palavras furtadas aos livros destinados às almas da elite - felicidade, embriaguez ou paixão - é parente da tentativa dos operários emancipados que reconstroem sua experiência cotidiana a partir das palavras desses herois românticos que sofrem por não terem "nada para fazer na sociedade" ou dos revolucionários que formulam a nova igualdade em termos extraídos da antiga retórica ou do texto evangélico. (Rancière, 2017, 27-28)

Operários que roubam pensamentos e sentimentos que não lhes pertecem, assim como a filha de camponeses que apropria-se de uma vida que tão pouco lhe é destinada. Histórias que, acredita o autor, aparecem na materialidade do sensível dos textos, dos gestos, das expressões no rosto, das marcas nos corpos, dos objetos que os rodeiam, em suma, na textura do real.

Para Sartre o desejo de ser e sentir-se outra de Emma Bovary teria sido seu crime, e não o adultério em si, assim como para o jornalismo burguês e para os intelectuais do século XIX, que aparecem nos arquivos de Rancière, o desejo de escrever como burgueses teria sido o crime dos proletários e não o fato de aliarem-se ao ideal comunista. A paixão e a poesia aparecem como os objetos de disputa exatamente por serem aquilo que escapa da ordenação que determina os espaços e tempos dos 
indivíduos. O adultério pode ser explicado racionalmente e até associado a uma ideia de natureza humana menos cultivada e, por isso mesmo, mais apta aos desvios morais. Assim como aliar-se ao ideal comunista é visto pelos intelectuais da época como uma maneira de organizar as massas de trabalhadores retirando-lhes dos vícios e da vagabundagem, organizando-lhes a ocupação dos tempos e espaços. Se a paixão de Emma e a poesia dos operários aparecem como aquilo que deve ser controlado, é exatamente por que desorganizam o espaço e o tempo, porque escapam à razão que deseja identificar um modo de ser a um modo de aparecer. Rancière denomina essa razão desordenadora de democracia, não a compreendendo como uma forma de governo, mas, antes, como um modo da razão política, "aquela que suspende essa harmonia pelo simples fato de atualizar a contingência da igualdade, nem aritmética nem geométrica, dos seres falantes quaisquer" (Rancière, 1996, p. 40-41). É o modo de partilha que opera uma desidentificação, arrancando alguém à pretensa naturalidade de uma ordem ou lugar. A democracia não deve ser compreendida como a forma de atuação do Estado, mas como um modo ou um tipo de partilha que opera uma reordenação capaz de tornar visível aquele que antes não o era, permitindo que seja ouvido aquele que antes era considerado como inapto à cena de fala.

Emma Bovary e os operários-poetas-revolucionários não foram os primeiros nem serão os últimos a serem condenados por seus crimes: sentirem-se já como aquilo que desejam ser, mesmo que vivendo como o que são. Esse desejo de ser e sentir-se outro pode ser pensado como a democracia capaz de operar uma revolução estética, um processo de reconfiguração dos modos de visibilidade e dos modos como este relaciona-se com um modo de ser. Dissociação ou desidentificação entre o conceito e a realidade, entre o aparecer e o ser.

\section{Banalidade do sensível e revolução estética}

Se o sensível é compreendido como aquela textura do real na qual podemos identificar a origem e destinação das coisas e das pessoas, ele é também, como Rancière dá a ver, 
aquilo mesmo que escapa a qualquer identificação ou ordenação possível. Podemos compreender, desse modo, que a leitura realizada por Rancière, tanto de Emma Bovary quanto dos operários-poetas-revolucionários, teriam como intuito mover as peças de lugar para deixar-lhes escapar às identificações. Ao deslocar seu pensamento das críticas já construídas anteriormente à personagem, o autor dá a ver como operariam uma relação naturalizada entre o conceito e a realidade, entre o ser e o aparecer. Relação esta que interessa ao autor desfazer. Mas não se trata de pensar uma desordenação completa no sentido de que haveria, de um lado, um olhar racional sobre Emma Bovary e, de outro, um olhar irracional. Antes, trata-se de pensar em dois modos da razão. Um modo policial, que considera cada elemento constituinte de uma narrativa como parte essencial na construção de um todo coerente. Nessa razão, a relação entre os elementos se dá em uma ordem causal, ou seja, um elemento é sempre causa ou efeito do outro. Desse ponto de vista, os desejos e gestos de Emma devem sempre ser explicados po alguma causa anterior, seja ela de ordem psicológica ou social.

Mas há, ainda, outro modo da razão: a democracia. Esta não estabelece nenhuma relação de ordem causal, tampouco compreende que cada elemento da narrativa deva contribuir para a configuração de uma imagem coesa. Ao contrário, a razão democrática ou política é aquela que suspende a ordem de causalidade, que introduz um elemento estranho que desvia a ordem das coisas. A explicação das ações, nela, torna-se impossível, pois, sem causa, não há como explicar a razão de um gesto. A partir desse ponto de vista os problemas apontados por Baudelaire e por Sartre nas atitudes de Emma Bovary deixariam de ser um problema. Baudelaire, afinal, buscava em uma ideia de natureza feminina as justificativas para o que chamou de virilidade da personagem. Não a encontrando, buscou uma causa para tal desvio na personalidade do escritor. Sartre, por sua vez, determinou que o imaginário nunca poderia ser traído pela realização dos sonhos na vida real. E, à sua maneira, buscou uma causa para esse desvio da personagem a partir de duas vias: uma análise psicológica de Gustave Flaubert e outra político-social do contexto em que viveu e no qual escreveu Madame Bovary. 
Para Rancière, porém, a busca pelas causas dos gestos ou ações de uma personagem não fazem mais que aprisioná-la a um espaço e tempo determinados. Interessa, antes, olhar o sensível por aquela outra razão, a política, e ver as revoluções aí operadas. A partir dessa ideia, vemos como o autor não se interessa tanto em interpretar um caráter psicológico de Emma Bovary, mas sim perceber na textura da escrita, aquilo que interrompe a lógica causal da narrativa. Isso não significa dizer que Rancière dilui completamente a história a ponto de não restar nela ordenação alguma, afinal, isso seria negar o modo como a própria narrativa se constroi. Antes, o que o pensamento do autor nos permite perceber são os momentos em que essa ordenação é desviada, deslocada; ou, ainda, os momentos em que a ordem de causalidade é suspensa por um elemento sensível. Como o momento no qual Emma descobre sua paixão por seu futuro amante, Léon, o escrivão. Antes mesmo da descoberta muitos elementos são fornecidos ao leitor sobre sua paixão, já o sabemos de antemão. O modo como ela se interessa por ele, muito mais que pelo próprio marido Charles, as caminhadas e conversas que compartilham, o interesse de um pela vida do outro, dentre outras coisas, aparecem como elementos do encadeamento lógico da história, no qual somo levados a compreender logo cedo sobre a paixão de Emma. Mas ela, apesar de todos os indícios daquilo que poderia criar nela certos efeitos da paixão, parece não perceber as causas.

Em um determinado ponto da narrativa, um capítulo termina assim:

Quanto a Emma, não se interrogava para saber se o amava. O amor, acreditava ela, devia chegar de repente, com grandes brilhos e fulgurações - tufão dos céus que cai sobre a vida, revira-a, arranca as vontades como folhas e carrega para o abismo o coração inteiro. Não sabe que, no terraço das casas, a chuva faz lagos quando as calhas estão entupidas, e ela permaneceu assim em sua segurança, quando descobriu subitamente uma rachadura na parede. (Flaubert, 2011, p. 192)

No capítulo que se segue ela subitamente descobre a paixão fulminante que sente por Léon. Não há, entre o evento 
da fenda na parede e a descoberta da paixão, nenhuma relação de ordem causal. Não há nenhum elemento que nos possa fazer afirmar que a descoberta da paixão seja consequência da percepção da fenda na parede; não obstante, após esta, descobre-se aquela. É nesse sentido que Rancière compreende que a escrita é a própria textura do real. A paixão de Emma Bovary aparece na rachadura da parede de sua casa, na textura da materialidade do sensível do lugar que habita. Achá-lo "encantador", ou não poder "desviar dele o olhar", ou lembrar "as suas outras atitudes em outros dias, frases que ele tinha dito, o som de sua voz, toda a sua pessoa" (Flaubert, 2011, p. 194-195); não são estas as razões que a fazem perceber estar apaixonada. Não são esses acontecimentos ou as conversas que tinham, o que nele a agradava, mas sim a fenda na parede de sua casa. A paixão deságua não a partir daquilo que explicaria racionalmente sua percepção, tão pouco dos sintomas analisáveis, mas sim de um elemento sensível inscrito na materialidade de uma coisa inanimada. Tal qual a história dos operárias é percebida na textura das coisas inanimadas, a paixão da filha de camponeses deságua a partir da textura do real. A percepção da fenda na parede afigura-se como um ponto de virada da narrativa a partir do qual nada pode ser deduzido, mas, ao mesmo tempo, a partir do que nada mais permanecerá como antes. Tudo se passa como se a construção narrativa da história fosse suspensa por uma fenda nas entrelinhas, da qual tudo derivaria sem que pudessemos reconstruir a lógica de uma ligação de causa e consequência, pois a fenda não é causa da paixão, tanto quanto esta não é consequência daquela.

$\mathrm{O}$ que Flaubert nos mostra - ou melhor, o que sua arte pensa -, é a ideia de que elementos sensíveis podem construir uma narrativa particular. Um modo de contar histórias no qual cada elemento pode fazer parte, sem que lhe caiba necessariamente uma funcionalidade específica dentro de um todo. Uma forma de pensamento na qual o sensível e a materialidade das coisas seriam testemunho das condições de possibilidade de nossas formas de vida. Assim funcionaria o olhar do senhor sobre os operários, aquele que vê "na materialidade dos trabalhos que executam e na rudeza dos ócios, no vazio do pensamento e 
no fenecimento da carne as marcas da pertença a uma raça inferior" (Rancière, 2012a, p. 239). Sensível que expressaria uma condição ordenada entre o ser e o aparecer, mas também, matéria que afeta os corpos e os move de lugar, desordenando tal ligação. Assim, Emma Bovary teria sido afetada pelas palavras lidas nos romances de folhetim a ponto de desejar vivê-las. O que está sendo colocado em questão por essas reflexões, as de Flaubert tanto quanto as de Rancière, é o poder de expressão das coisas. O poder das coisas sensíveis de constituir as formas de visibilidade que apresentam o mundo que habitamos - como no olhar do senhor -, tanto quanto modificam essa apresentação - como a filha de camponeses vivendo as paixões da elite.

O que aparece como ponto comum entre a leitura rancieriana de Madame Bovary e das revoluções operárias é a capacidade do sensível, do inanimado, de pensar e de afetar e mover as figuras de lugar. A novidade da revolução operária, tanto quanto da literatura romanesca de Flaubert, seria o surgimento de um modo de pensamento que comportaria um excedente, de um excesso que extravasaria a totalidade, seja da ordenação social no primeiro caso, seja da narrativa no segundo. Tudo se passa como se houvesse uma suspensão entre o corpo operário, sua função, e sua identificação, ou uma fenda entre o corpo e a letra, as palavras e as coisas, a imagem e o textol; uma revolução sensível. Essa racionalidade da fenda estaria em oposição a um modo de pensamento no qual cada elemento da narrativa só poderia ali estar se estabelecesse uma função específica em relação ao todo, no qual uma identificação social estaria ligada a uma função e a um espaço próprios.

Para Rancière,

a poesia, em primeiro lugar, não é uma maneira de escrever, mas uma maneira de ler e de transformar o que se leu em maneira de viver, de fazer disso o suporte de uma multiplicidade de atividades: errar e vaguear, refletir, fazer a exegese, sonhar. (Rancière, 2017, p. 83)

Em um modo de pensamento que busca a causa para cada gesto que parece desviar da narrativa, ou para cada ação que desloca uma identifcação, não caberia à literatura, vaguear, 
errar, e tão pouco ao operário, pensar ou ser poeta. No modelo de racionalidade que surge na revolução operária tanto quanto na literatura de Flaubert, a escrita é pensada como um "trajeto de letra desincorporada que pode tomar qualquer corpo." (Rancière, 1995, p. 41). A letra, assim considerada, não tem corpo, não possui dono, autor ou domínio próprio. Tão pouco é destinada a um interlocutor específico; ao menos não sem correr o risco de sofrer um desvio no caminho. A letra, aquela que levaria a verdade ao encontro dos corpos, pode transmutar-se em qualquer forma, pode tomar a forma de qualquer corpo, extravazando qualquer limite que se empenhe por naturalizar seu espaço.

É isso que o autor compreende como democracia na literatura, democracia romanesca, democracia ficcional, democracia literária (Rancière, 2017). É o ser literário cujo modo do pensamento é suspensivo, desviante, cheio de fendas de sensibilidade que modificam tudo que lhes toca, sendo impossível reconstruir as razões dessa relação. Sem que seja possível pensar uma ligação causal entre a fenda na parede de Emma Bovary e a paixão que deságua. Sem que seja possível estabalecer uma relação causal entre a virilidade de Emma ou seu desejo de realizar na vida os sonhos do imaginário, e uma explicação psicológico ou política social da vida do autor.

Uma gota de neve fundida caindo sobre a sombrinha de Emma, um inseto sobre uma folha de nenúfar, gotas de água ao sol, nuvem de poeira de uma diligência. São esses quadros, essas impressões fugazes e passivas que desencadeiam os acontecimentos amorosos. É como se a pintura viesse tomar o lugar do encadeamento narrativo do texto. Esses quadros não são simples cenários da cena amorosa: não há nenhuma analogia entre um inseto sobre uma folha e o nascimento de um amor. Portanto, não são complementos da expressividade trazidos à narração. (Rancière, 2012d, p. 117)

As folhas, a água, a poeira excedem a narrativa, são elementos desprovidos de função, passivos. E, no entanto, modificam o curso da narrativa, modificam a vida de Emma Bovary. Nas noites proletárias (Rancière, 2012a), o alfaiate que funda um jornal operário, o fabricante de medidas que compõe canções, o carpinteiro que escreve poesia, o limpa-latrinas boêmio, excedem a ordenação 
social e mudam a divisão dos espaços e tempos. Pensar a noite dos proletários significa, diz Rancière, pensar

a história das noites arrancadas a sucessão normal do trabalho e do descanso: interrupção imperceptível, inofensiva, dir-se-á, do curso normal das coisas, onde se prepara, se sonha, se vive já o impossível, a suspensão da ancestral hierarquia que subordina aqueles que estão destinados a trabalhar com as mãos aos que receberam o privilégio do pensamento. (Rancière, 2012a, p. 8)

\section{Considerações finais}

Interrupção, suspensão, desvio, fenda. Vai-se construindo com isso uma teia de aranha que atravessa a escrita rancieriana, mas que atravessa também a vida de Emma Bovary e das tantas personagens que tiveram suas vidas modificadas pelo encontro com esse estranho sensível do ser literário. Surgem, com isso, imagens de fios perdidos do sensível que excedem a ordenação, social e narrativa, que suspendem, desviam, interrompem as linhas de racionalidade propostas; fios que podem, como argumenta - e, acreditamos, também o faz -, Rancière, "raspar as imagens, não para que o verdadeiro se revele mas para as mover, de modo que outras figuras aí se componham e decomponham" (Rancière, 2012a, p. 21). Quando se parte de uma tal leitura, pautada na materialidade do sensível, a própria ligação da arte com a política não pode mais passar por uma discussão sobre a identificação da burguesia com o proletariado, tampouco em relação à práxis política, tal qual fazia Sartre. Afinal o processo político, como compreendido por Rancière, passa, antes, por um processo de desidentificação e a própria oposição entre passividade e atividade deixa de ser interessante quando se pensa que a textura do sensível, que o inanimado, operam algo no real; quando se pensa que as coisas inanimadas podem operar uma revolução sensível.

Acreditamos, assim, que a leitura feita por Rancière em relação à Madame Bovary, ao ser comparada com as eituras anteriores, não apenas reinterpreta o livro de Flaubert, mas também recoloca a questão da ligação entre arte e política a partir 
de um outro ponto de vista. Já não se trata mais de pensar que a arte educaria o público ao desvelar a lógica do capital que este não compreenderia, mas antes, pensar que a arte forneceria outras visões de mundo, outras texturas do real que modificariam os modos de sentir. É uma mudança de sensibilidade que está em jogo e não um processo de conscientização política. Tal ideia põe fim a distância entre as inteligências, afinal,

compreender não é mais do que traduzir, isto é, fornecer o equivalente de um texto, mas não sua razão. Nada há atrás da página escrita, nenhum fundo duplo que necessite do trabalho de uma inteligência outra, a do explicador; nenhuma lingua do mestre, nenhuma lingua da lingua cujas palavras e frases tenham o poder de dizer a razão das palavras e frases de um texto. (Rancière, 2010, p. 27).

Desse modo, a abordagem de Rancière em relação ao livro Madame Bovary daria a ver, não apenas uma nova crítica literária, mas um novo modo do pensamento para pensar a literatura e as outras artes assim como as questões políticas e sociais. Um modo que não aprisiona a sensibilidade das coisas a uma ordenação causal que identifica um conceito a uma realidade. O que o autor fornece é a possibilidade de pensarmos a sensibilidade por aquilo que ela revoluciona, por aquilo que faz desviar a ordem comum das coisas, pela suspensão das relação naturalizada entre os espaços e os indivíduos.

\section{Referências}

BARNES, Hazel E. Sartre \& Flaubert. Chicago: The University of Chicago Press, 1981

BAUDELAIRE, Charles. Madame Bovary por Gustave Flaubert. In: Madame Bovary: costumes de província. Trad. Mario Laranjeira. São Paulo: Penguin Classics Companhia das Letras, 2011

FLAUBERT, Gustave. Madame Bovary: costumes de província. Trad. Mario Laranjeira. São Paulo: Penguin Classics Companhia das Letras, 2011

JAMESON, Fredric. Sartre in search of Flaubert. The New York Times, 27 dez. 1981. Disponível em: http://www.nytimes. com/1981/12/27/books/sartre-in-search-of-flaubert.html?pagewanted=all. Acesso em: 2 mar 2018 
PORTER, Laurence M.; GRAY, Eugene F. Gustave Flaubert's Madame Bovary: a reference guide. Westport: Greenwood Press, 2002.

RANCIÈRE, Jacques. A noite dos proletários. Trad. Luís Leitão. Lisboa: Antígona, 2012a.

RANCIÈRE, Jacques. A partilha do sensível: estética e política. Trad. Mônica Costa Netto. São Paulo: Ed. 34, 2009a. 2009

RANCIÈRE, Jacques. O desentedimento: política e filosofia. Trad. Ângela Leite Lopes. São Paulo: Editora 34, 1996.

RANCIÈRE, Jacques. O espectador emancipado. Trad. Ivone C. Benedetti. São Paulo: WMF Martins Fontes, 2012d. 2012b

RANCIÈRE, Jacques. O fio perdido: ensaios sobre a ficção moderna. Trad. Marcelo Mori. São Paulo: Martins Fontes, 2017

RANCIÈRE, Jacques. O mestre ignorante. Trad. Lílian do Valle. Belo Horizonte: Autêntica, 2010b.

RANCIÈRE, Jacques. Políticas da Escrita. Trad. Raquel Ramalhete. Rio de Janeiro: Editora 34, 1995.

SARTRE, Jean-Paul. O idiota da família: Gustave Flaubert de 1821 a 1857. v. 1. Trad. Ivone C. Benedetti. Porto Alegre: L\&PM, 2013.

SARTRE, Jean-Paul. O idiota da família: Gustave Flaubert de 1821 a 1857. v. 2. Trad. Ivone C. Benedetti. Porto Alegre: L\&PM, 2014.

SARTRE, Jean-Paul. O idiota da família: Gustave Flaubert de 1821 a 1857. v. 3. Trad. Ivone C. Benedetti. Porto Alegre: L\&PM, 2015. 